\title{
A Multi-Pronged Approach to Work Integrated Learning for IT Students
}

\author{
Lorraine Staehr, Mary Martin, and Ka Chan \\ Department of Computer Science and Computer Engineering, \\ La Trobe University, Bendigo, Australia
}

\author{
l.staehr@latrobe.edu.au m.martin@latrobe.edu.au \\ Ka.Chan@latrobe.edu.au
}

\begin{abstract}
This paper describes the multiple work integrated learning (WIL) schemes available to IT students at La Trobe University, Bendigo Campus. Having a number of different options for students to choose from maximizes the number of students who can have the opportunity for IT industry experience while completing an IT degree. This approach is important since IT employers are currently more likely to employ work-ready graduates. The advantages of the programs to the various stakeholders - university, IT academic staff, industry partners (IP) and students (regardless of whether they participate in a WIL program or not) - are outlined. To differentiate work integrated learning from work experience there is an emphasis on reflective practice throughout the IT work-integrated learning subjects. Some examples of students' reflective writing are provided to illustrate this focus. Suggestions for successful WIL programs are discussed along with issues that have arisen and how they were managed.
\end{abstract}

Keywords: Work integrated learning (WIL), IT industry, reflective practice.

\section{Introduction}

In Australia work place learning was traditionally the sole domain of higher education degrees such as health, engineering and teacher education. However, more recently due to calls from employers for work ready graduates, there has been an increasing trend in Australian universities for work integrated learning (WIL) to be implemented across a much broader range of university degrees. Industry wants more involvement in training to address low productivity and skill shortage concerns (Australian Industry Group, 2011). The expansion of WIL across all academic disciplines should make university graduates more attractive to employers. Major reports funded by the Australian Learning and Teaching Council (Billitt, 2011; Orrell, 2011; Patrick et al., 2008)

Material published as part of this publication, either on-line or in print, is copyrighted by the Informing Science Institute. Permission to make digital or paper copy of part or all of these works for personal or classroom use is granted without fee provided that the copies are not made or distributed for profit or commercial advantage AND that copies 1) bear this notice in full and 2) give the full citation on the first page. It is permissible to abstract these works so long as credit is given. To copy in all other cases or to republish or to post on a server or to redistribute to lists requires specific permission and payment of a fee. Contact Publisher@InformingScience.org to request redistribution permission. and Universities Australia (2008) have provided guidelines and examples of best practice for curriculum designers to integrate work-based learning into the student experience.

It is only since the start of the $21^{\text {st }}$ century that WIL has become a topic for higher education researchers e.g. (Lester \& Costley, 2010; Smith \& Worsfold, 2013). This educational research has provided important evidence about the 
type of learning that takes place in the work environment in contrast to formal learning in university. In addition, it has been shown that WIL can increase a student's motivation to learn and contribute positively to the student's overall learning experience at university (Cooper, Orrell, \& Bowden, 2010).

WIL is particularly valuable for IT students since career options in IT are many and varied (Commonwealth of Australia, 2013). Through WIL students may gain experience in more than one role, becoming more knowledgeable about the type of career path they want to pursue and the IT industry. Having some IT experience means students are also in a better position when they graduate, since this makes them more 'work ready', hence attractive to prospective employers.

The rest of the paper is organized into a number of sections. The first, the background section, outlines the degrees that the WIL programs are available in and the broad aims of the WIL programs. In the second section the WIL programs available to students are explained in detail. This is followed by a third section with examples of reflective practice and student learning in the context of the WIL programs. The fourth section covers lessons learnt from the WIL programs, and the final section provides some concluding remarks.

\section{Background}

There are a number of terms used to describe workplace learning, and it is appropriate to specify what type of workplace learning this paper is addressing. It seems easier to start with the type of workplace learning this paper is not addressing. It is not dealing with work experience, which in Australia is commonly undertaken by secondary school students for a week or so with the aim of presenting them with future career options. These placements are voluntary or at most involve a very small token payment, and students are not formally assessed. Neither is this paper addressing work-based learning programs where industry and a university collaborate to allow professional development and other work place courses to be used as credit towards a degree (Cooper et al., 2010). Instead, WIL in this paper consists of one of two types of programs. In the first a student completes a subject or subjects that form part of an information technology (IT) degree program while in the work place. These subjects are coordinated by a university academic and involve formal academic assessment combined with assessment of performance in the workplace. The student receives either a salary or a scholarship from the employer. The second type of program is where the student completes the whole IT degree part time while working for an organization in an IT role.

The Department of Computer Science and Computer Engineering at La Trobe University, Bendigo campus offers two Australian Computer Society (ACS) accredited degree programs, the Bachelor of Information Technology and the Bachelor of Information Technology (Professional). Most students combine information technology (IT) studies with subjects from business or science. In order to maximize opportunities for students to undertake WIL in these degrees a number of different WIL options have been introduced since the first scheme began in 1995. Specifically, the main aims of the WIL programs at La Trobe University, Bendigo campus are to:

- $\quad$ provide the opportunity for undergraduate students to learn from the practical experience of solving real world problems in the work place while building on concepts learned in prior course work,

- assist the university to maintain awareness of industry needs in IT undergraduate education, and

- foster mutually beneficial relationships between the industry partners (IPs) and the university. 


\section{WIL at La Trobe University, Bendigo}

The various WIL schemes available to students are shown in Table 1. Each scheme arose to address particular university and/or IP requirements and an explanation of the origin of each of the WIL programs follows. The first scheme, the Industry Based Learning (IBL) scholarship program, was initially designed to increase collaboration between the University and the IP. This program is for high achievers and is available to students in the final year of their course. The second scheme, the industry experience program, was designed as an alternative for employers who wished to employ full time and support a final year student for a period of one or two university semesters. The third scheme, industry placement, was introduced so that IT students gaining paid part time IT positions (usually IT support) with employers could undertake assessment of that work. This option is available to students after completing the first year of the degree. Finally, the IT cadetship addressed the University's need to increase student numbers and the IT industry's need for more degree-qualified IT graduates. In contrast to the other schemes the cadetship is available to students commencing the first year of the degree. In the following sub-sections each scheme is described in some detail and discussed in its chronological order of introduction to the degrees.

\section{Industry Based Learning (IBL) Scholarship}

The IBL program is a true educational partnership. In other words it is more than simply work experience for the students. There is ongoing interaction throughout the industry placement between an academic staff member, the industry supervisor and the student. This program has shown that universities and IPs can work together to provide real educational as well as work experience benefits for students. Student reflective diaries (see examples in the section 'Reflective Practice and Student Learning" below) provide anecdotal evidence that this has occurred.

The Bachelor of Information Technology (Professional) degree includes the IBL program within its course structure. Students must obtain a high university entrance score (Australian Tertiary Admission Rank (ATAR) score of at least 80.0) to gain entrance into the degree. An alternative path into the IBL program is where students in the standard Bachelor of Information Technology apply after successfully completing two years and are judged on their academic performance within the degree. Students submit a written application including a resume and cover letter. If their academic performance is suitable, selection proceeds with an initial interview with a panel comprising two IT academic staff and a careers advisor. After this initial interview at the university students receive feedback on their application and performance at the interview. They are offered assistance to improve any shortcomings. The students who successfully pass this part of the process proceed to an interview with the IPs at an IP site where the final selection occurs.

Before placements commence the careers advisor provides a session on the Australian work place which is particularly useful for international students. Topics include the skills that employers value, what employers don't want, what to expect and how to handle the first few weeks, work place protocol, creating the right impression, time management, enhancing your work place profile, and coping with change.

Each student undertakes a 20-week placement with each of two IPs. The students are supported by scholarships funded by the IPs and administered by the university. They work on IT projects under the guidance of the IP and university IT academic staff. Students are given academic credit for four level-3 subjects ( 60 credit points) for the two 20 -week placements. 


\begin{tabular}{|c|c|c|c|c|c|c|c|c|c|c|c|c|}
\hline \multirow{5}{*}{ 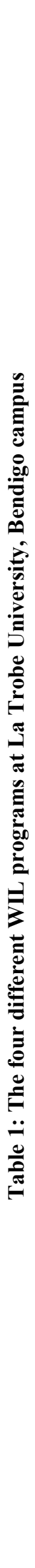 } & 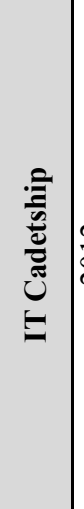 & & 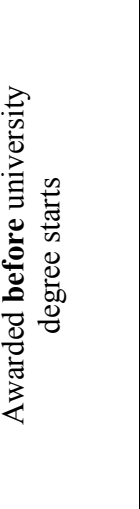 & & 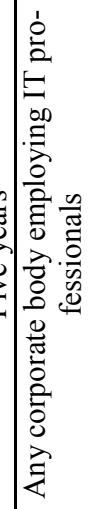 & 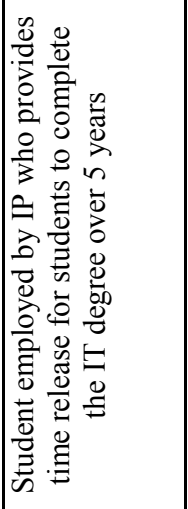 & 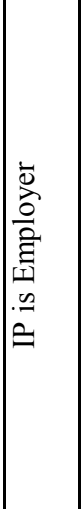 & 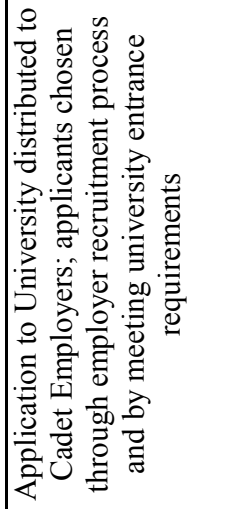 & 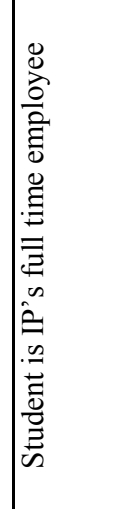 & 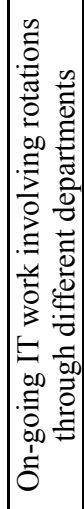 & 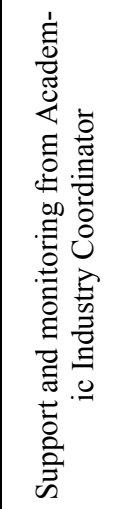 & 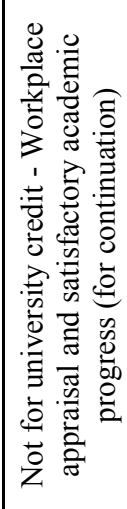 \\
\hline & 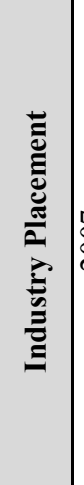 & 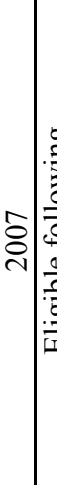 & 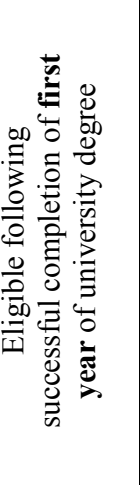 & 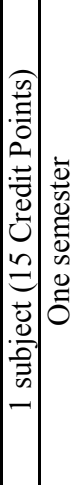 & 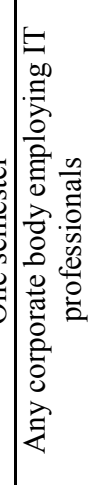 & 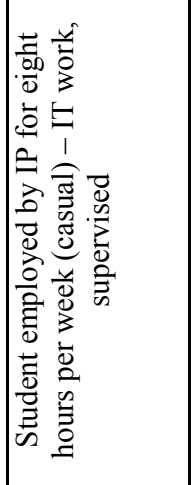 & 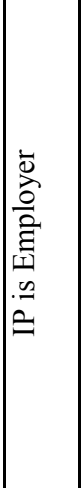 & 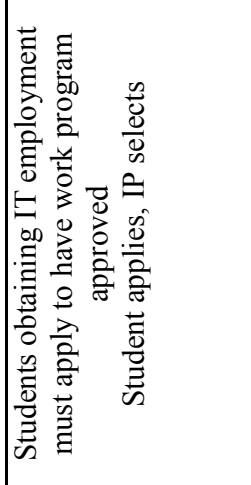 & 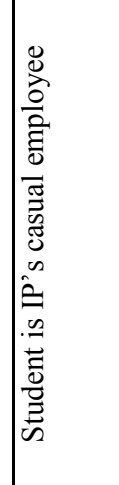 & $\vec{z}$ & 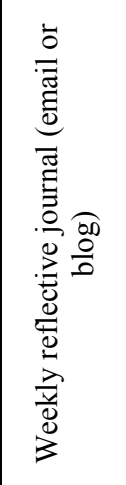 & 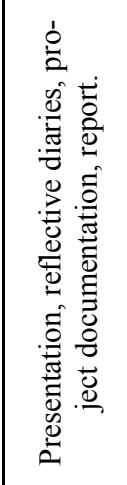 \\
\hline & 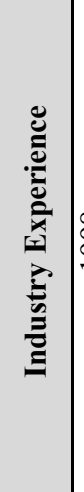 & 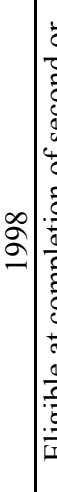 & 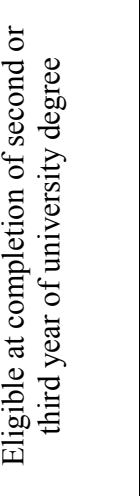 & 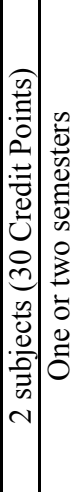 & 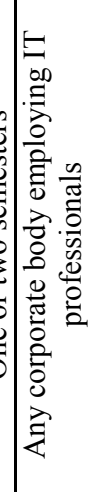 & 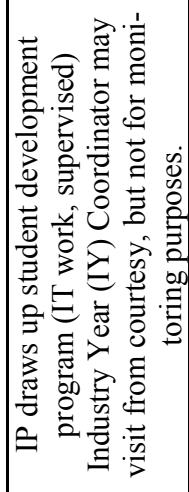 & 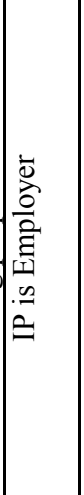 & 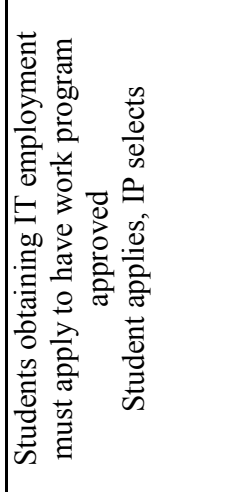 & 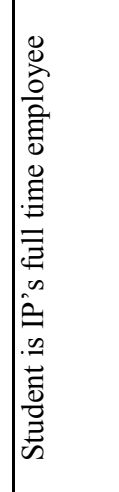 & $\vec{z}$ & 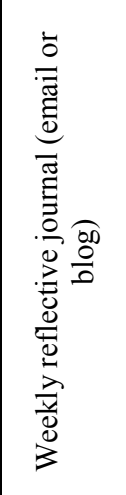 & 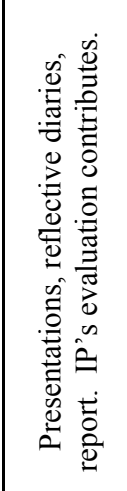 \\
\hline & 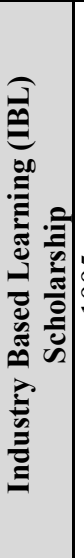 & & 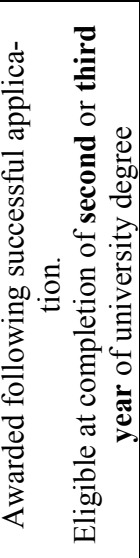 & 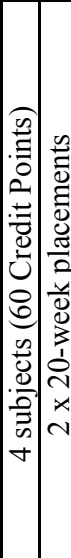 & 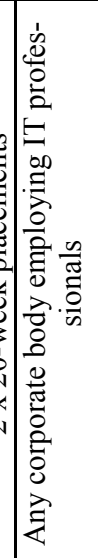 & 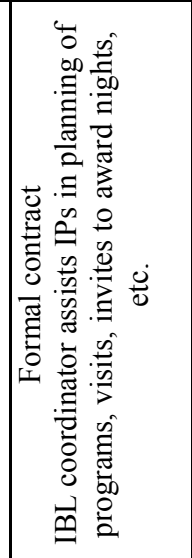 & 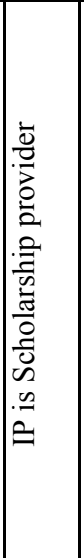 & 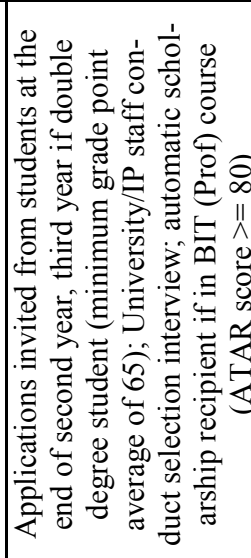 & 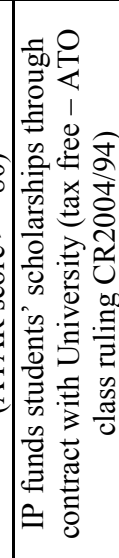 & 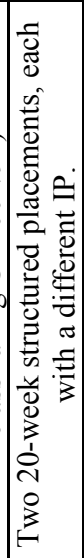 & 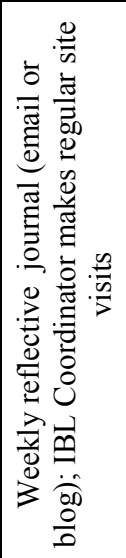 & 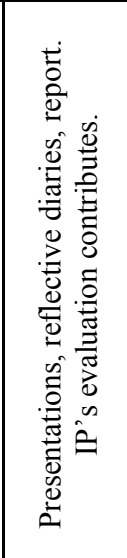 \\
\hline & 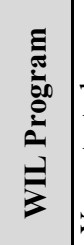 & 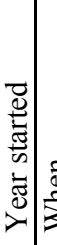 & छี & 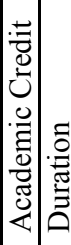 & 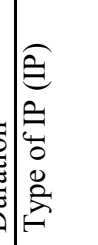 & 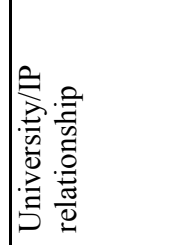 & 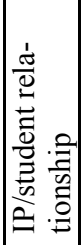 & 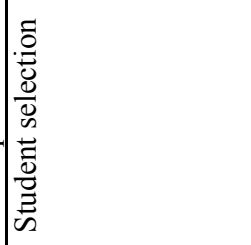 & 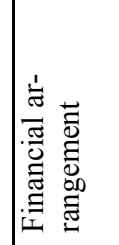 & 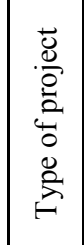 & 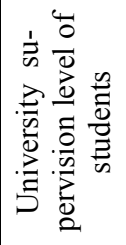 & 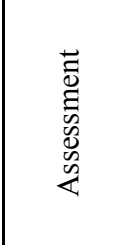 \\
\hline
\end{tabular}


There is close collaboration between the industry supervisor and the academic supervisor throughout the placement to ensure that appropriate work is assigned to the student and that any problems that arise are addressed promptly. To this end the academic supervisor conducts three site visits at the beginning, middle, and end of a 20 -week placement. During the visit the industry supervisor provides feedback to the student in the presence of the academic supervisor. Students are required to reflect on their learning experiences by providing weekly email journal entries to the academic supervisor throughout the two placements. The students also give presentations at the secondary school that they attended, thus promoting the IT degrees at La Trobe University and IT as a career option. They complete their placements by giving formal presentations at the university (industry supervisors are invited to attend) and submitting a final report for assessment by the academic supervisor.

IPs support the scheme financially by

- funding tax free student scholarships,

- subsidizing accommodation costs for the students whose placements are outside Bendigo, and

- covering university administration costs.

\section{Industry Experience}

This program arose in response to the desire of a potential IP to simply employ final year IT students rather than provide a scholarship arrangement and be involved in the close level of collaboration that is a feature of the IBL program. The University was not required to conduct initial interviews and in many cases since its introduction in 1998 the student has already been employed by the organisation. The student has the opportunity to do up to two level-3 WIL subjects (30 credit points) while working full time in the IT industry. A work program for each subject must be approved by the academic supervisor, but no site visits are required. A courtesy visit is usually conducted for local IPs. Each subject requires weekly reflective diaries to be submitted to the academic supervisor for formal assessment. A final report and presentation on the IT work undertaken, and the employer's supervisor appraisal of the student also forms part of the assessment.

\section{Industry Placement}

Although relatively recent (2007), an IP was again the impetus for developing another program, the Industry Placement. It differs from the first two options in two main ways: it is available to the student after completion of the first year of the IT degree, and it requires suitable IT employment only on a part time basis for a minimum eight hours. This program is worth one level-2 WIL subject (15 credit points). This option is popular with students working part time for IPs local to the University. The student meets with an academic supervisor at regular intervals throughout the semester and maintains a weekly reflective diary. The assessment consists of a written report, including the diary as an appendix, and a presentation on both the workplace experience as well as a study on some aspect of the IT work that the student has undertaken. This might be a software product including documentation or an investigative report on a topic such as IT service management.

\section{IT Cadetship}

This most recently introduced WIL program (2012) differs from the other options in a number of ways. Rather than being available to a student during the degree, it is primarily intended for someone yet to commence an IT degree. Prospective students apply for the cadetship separately to their application into the IT degree. Information sessions are provided for students and parents. Applicants are interviewed by the IPs offering cadetships before acceptance into the degree. Industry experience is recognised by incorporating the four WIL subjects associated with the IBL program into the final year of the cadetship. 
The program was designed to address the two major issues facing the ICT sector in regional Victoria. For IPs it was the difficulty of attracting and retaining sufficient numbers of skilled IT professionals and for the University it was the low numbers of applicants for IT courses. This WIL option is particularly valued by parents since students receive a cadet salary throughout the five years of the cadetship. The cadet:

- works full time with time allowance for attending university studies

- $\quad$ studies part time at university (approximately 8 hours of classes per week)

- works full time outside university semester periods

- earns cadet salary determined by employer

- is provided with financial assistance for study costs (e.g. text books) and accommodation (optional)

- is provided with training and development programs by the IP (optional)

- undergoes IP's work performance appraisals and university academic performance reviews to assist development and performance

- is subject to a consultation process that may result in cadetship termination if unsatisfactory work performance or unsatisfactory university results

- is mentored and supported by an IP workplace coach

- is academically assessed and supported by a dedicated academic Industry Coordinator through workplace visits, reflective diaries, presentations (internal and external) and written reports.

This program, together with the other programs described above, is promoted collectively by the University as the Industry Integrated Bachelor of Information Technology (IIBIT) program. Its success was recognised at the National Australian Business/Higher Education Round Table (BHERT) Awards in 2012 when it received an Honourable Mention for Outstanding Achievement in Higher Education and Training Collaboration.

\section{Reflective Practice and Student Learning}

The major distinguishing feature between work experience and WIL at La Trobe University, Bendigo campus is that WIL students are required to write weekly and reflect on their experiences in the work place in terms of learning and professional practice (Schon, 1991). This does not come easily to students so they are given an example of reflective writing (Wotton, Collings, \& Moon, 2001 ) and asked to evaluate their early attempts at reflection. Here is one example of selfevaluation:

"After reading the Reflective Writing article I can see that I can include more reflection on my actions and how I might have done things differently. Maybe I could of have included what I would of [sic] done differently next time to achieve greater learning or understanding. I could have also included some more information about ethical issues, because there are a number of ethical issues that arise when working at a bank. MIRC also has access to and works with a lot of sensitive data and this is a topic I could talk about more." (Student B)

\footnotetext{
The following are quotes from weekly reflective diaries showing the type of reflection that is required from students. They can be grouped under the type of learning that is an outcome of the WIL experience.

Students appreciate the relevance of the content in university subjects:

"I realised too, how helpful the use of diagrams can be in consolidating what knowledge you have about something. I was asked to construct a diagram linking together all of the different components that require changing for the eBanking change I am working on, and this helped consolidate and increase my understanding of how it all goes together. Having to know, correctly, what affects everything else and in what ways, tests what you think you know. Some of my uni units involved creating many diagrams, and now I understand why a bit more!" (Student G)

Students learn new IT or professional skills:
} 
"I think the key thing I took away this week was how to act in a business meeting. Most of our team and office meetings are fairly informal situations. With the teleconference it was important to maintain business language and speak in turn. Not new concepts but quite interesting when you can't see the person you are conversing with." (Student A)

"This week I also gained some confidence in my abilities and skills because the deployment of the Time Register went well. I was confident but still hopeful that users would find the program easy to use and an improvement from the old program." (Student B)

"This week I think I can improve my public speaking some more. In my demo that I gave in the meeting I did feel a bit uncomfortable at times. In my last placement I was speaking in public quite frequently so I became familiar and more comfortable with the practice. However having not done that sort of thing for a while and can be a little daunting. I think my best course of action is to go into these situations with confidence in myself and what I am presenting. It is something I would like to improve and I think practice is the best way to go about it." (Student B)

"This week I have learnt the valuable lesson of the dangers of having all of the information stored within one person's head. By Wayne being on leave this week it has severely hindered our testing and essentially put us back on some fronts as we have been unable to move forward without his expertise." (Student E)

Students reflect on new (to them) approaches to learning:

"Whilst I feel much more confident with the processes I know I still need to try and understand it more. NO good being able to blindly do something if you don't understand how it works." (Student A)

"Sometimes having another brain look at a problem can provide solutions. My solutions can be either to complex, inaccurate or not viable. Talking to other people can be help to either think through a problem or bring to light a solution." (Student C)

"Before the training session I was telling one of the team members about how I was getting worried about not doing the best job I could do in the short time I had left. He reassured me that I can only do my best and it is better to have the chance to fix up some of the problems than to have them appear after I've gone, also that we're not perfect and they don't expect a perfect product, that as long as I've done my best that's all they ask. This reassured me as I know I can be a bit hard on myself and to hear someone being more understanding with me than I was, was encouraging and it help set my mind at rest. " (Student D)

Students gain confidence in their own abilities:

"I have also learnt that I myself can be a resource to other people too, with my new found knowledge of CIS OV I have come to realise that others don't have much to do with CIS therefore they are quite blind to its functionality. With this being said I have been approached at times by other members to ask how the system works or to ask me to do things to set up processes for their end to receive the outcome. I have actually enjoyed this as it's really making me feel as part of the team and I am also taking on new jobs of my own, not just constantly going back to Steve or Martin to ask for something to do. I am rarely sitting at my desk with nothing to do." (Student E)

Students come to terms with life-long learning:

"As long as we are alive we keep learning, observing and grasping thing from our day to day life. This week turned out to be a good in learning aspects. I am adapting professional way of contacting people in my daily life. It's not just my emails, but even my phone messages to my house owner for rent purpose are well structured now. I know it sounds funny but I have realized the change in myself. My new idea of booking test machines is being well adapted by others and it's turning out to be helpful in avoiding hindrance in others work. By getting stuck and tackling frequent is- 
sues within same packaging requests has [sic] helped me to develop patience in resolving issues ... I guess the more I get stuck, the more I will learn". (Student F)

Students come to appreciate the wide variety of IT careers available to them:

"Talking with staff members about career paths, and learning in general (through talking about uni and about being a student) opened my eyes a lot more as to what is out there, and also how great of an opportunity I have with my IBL placement. The number of different jobs just in the bank's IT department alone is more than I really knew existed. It has given me more of an idea of what to focus on in my mid-semester presentation too, so that I can hopefully engage the audience and get them thinking about their future career plans (hopefully in IT). I want to open their eyes as to the scope of IT, highlighting that there are almost certainly more jobs out there involving IT than they could possibly know without seeing it first-hand (one of the reasons why IBL is so important and such a great opportunity)." (Student G)

"I have been thinking that organizations prefer people with multiple skills. Organizations use the resources (us) in best possible way. Franklin was actually hired as a SOE builder but as soon as he finished with major part of SOE build for the Integration Project, he was transferred from network department to our packaging department. So I guess a versatile employee is given more preference and proves to be more beneficial for the organization. During this week I have spent my free time by interacting with Franklin in test \& build room. I have actually tried to explore other related areas of work by communicating with professionals from other departments. This way I am able to know about the possible opportunities of work and also the kind of skills the organizations look for while hiring an employee." (Student F)

\section{Lessons Learnt}

There are clear benefits of WIL for the student, IT academics, the university, and the IP. These are summarized in Table 2 below. A really positive outcome from the WIL programs has been the involvement of IT industry professionals in the delivery of academic subjects. For example, in one second year subject an IT project/program manager collaborates with the academic to deliver the three week project management part of the subject. In a final year subject, a panel of three IT industry professionals attends and provides feedback at student debates and presentations on current ethical and social issues in IT. This has been instrumental in raising the standard of work produced by the students in these subjects since the IT industry professionals are prospective employers.

Most of the issues have occurred with the longest running WIL program, i.e., the IBL program. First, the Australian Tax Office ruling on the tax free scholarship clearly states that students are full time students of La Trobe University while participating in the IBL program. However Centrelink (the Australian Government Department of Human Services) insists on classifying the students as part time according to the number of credit points associated with the IBL subjects. This is an ongoing problem. A second issue is that the contract with the IP needs to be written so that it is clear that the students are students of the university while participating in the program and not employees of the IP. This is necessary so that the IP does not have to pay Australian payroll taxation. Third, legal advice has indicated that ultimately the academic supervisor is responsible for appropriate occupational health and safety conditions for students in the work place. Finally, the administrative burden on the academic supervisor can be onerous and as much administration for the program as is possible should be done by university professional staff. 
Table 2: Benefits of the WIL programs

\begin{tabular}{|c|c|c|c|c|}
\hline Stakeholder & $\begin{array}{l}\text { Industry Based } \\
\text { Learning }\end{array}$ & Industry Experience & Industry Placement & IT Cadetship \\
\hline IP (IP) & $\begin{array}{l}\text { - Fresh skills and en- } \\
\text { thusiasm } \\
\text { - Tax deductibility of } \\
\text { student scholarship } \\
\text { - Test best students as } \\
\text { future employees }\end{array}$ & $\begin{array}{l}\text { - Timely availability } \\
\text { of successful job } \\
\text { candidate } \\
\text { - Potential for Univer- } \\
\text { sity assistance if stu- } \\
\text { dent has problems }\end{array}$ & $\begin{array}{l}\text { - Opportunity to quickly } \\
\text { fill casual positions } \\
\text { - Increased opportunity } \\
\text { to attract local gradu- } \\
\text { ates }\end{array}$ & $\begin{array}{l}\text { - Access to high achieving } \\
\text { students as employees, } \\
\text { and } \\
\text { - Increased interaction } \\
\text { with the university from } \\
\text { which other collabora- } \\
\text { tions arise. }\end{array}$ \\
\hline Student & $\begin{array}{l}\text { - Tax-free scholarship } \\
\text { linked to Consumer } \\
\text { Price Index(CPI) plus } \\
\text { accommodation sub- } \\
\text { sidy if student place- } \\
\text { ment is in Melbourne. } \\
\text { - Experience helps to } \\
\text { differentiate student } \\
\text { from others on gradu- } \\
\text { ation } \\
\text { - IP becomes at least a } \\
\text { source of references, } \\
\text { maybe a future em- } \\
\text { ployer } \\
\text { - Increased confidence } \\
\text { and awareness of ca- } \\
\text { reer options }\end{array}$ & $\begin{array}{l}\text { - Employment } \\
\text { - Academic credit } \\
\text { while fully em- } \\
\text { ployed } \\
\text { - Real employment } \\
\text { experience gained, } \\
\text { with academic bene- } \\
\text { fits } \\
\text { - Increased confidence } \\
\text { - Increased probability } \\
\text { (given that they have } \\
\text { chosen to start work } \\
\text { before graduating) } \\
\text { that student will } \\
\text { complete degree }\end{array}$ & $\begin{array}{l}\text { - Casual employment } \\
\text { - Academic credit for } \\
\text { practical IT } \\
\text { knowledge } \\
\text { - Real employment } \\
\text { experience gained } \\
\text { while studying with } \\
\text { academic benefits } \\
\text { - Increased confidence } \\
\text { - Increased probability } \\
\text { that student will com- } \\
\text { plete degree }\end{array}$ & $\begin{array}{l}\text { - Full time cadet salary } \\
\text { (determined by employ- } \\
\text { er) } \\
\text { - Training and develop- } \\
\text { ment programs offered } \\
\text { by employer } \\
\text { - Mentoring and support } \\
\text { from a workplace coach, } \\
\text { allocated within the or- } \\
\text { ganization to oversee } \\
\text { day-to-day work, answer } \\
\text { questions and provide } \\
\text { advice } \\
\text { - Additional support } \\
\text { through a dedicated Aca- } \\
\text { demic Industry Coordi- } \\
\text { nator, who will monitor } \\
\text { student progress }\end{array}$ \\
\hline $\begin{array}{l}\text { University, } \\
\text { staff, other } \\
\text { students, com- } \\
\text { munity }\end{array}$ & $\begin{array}{l}\text { - Promotes relations } \\
\text { with IPs } \\
\text { - Feedback in presenta- } \\
\text { tions, and in subse- } \\
\text { quent classroom sub- } \\
\text { jects, about observed } \\
\text { current work practices } \\
\text { - IP supports Universi- } \\
\text { ty administration } \\
\text { costs } \\
\text { - IP staff involvement } \\
\text { in academic subjects }\end{array}$ & $\begin{array}{l}\text { - Promotes relations } \\
\text { with IPs } \\
\text { - Makes student com- } \\
\text { pletion of the degree } \\
\text { more likely } \\
\text { - Assists provision of } \\
\text { IT skills in the re- } \\
\text { gion }\end{array}$ & $\begin{array}{l}\text { - Promotes relations } \\
\text { with IPs } \\
\text { - Makes student com- } \\
\text { pletion of the degree } \\
\text { more likely } \\
\text { - Helps provide skills in } \\
\text { the region } \\
\text { - Increased attractive- } \\
\text { ness of IT courses to } \\
\text { potential students }\end{array}$ & $\begin{array}{l}\text { - Promotes relations with } \\
\text { IPs } \\
\text { - Helps provide skills in } \\
\text { the region } \\
\text { - Increased attractiveness } \\
\text { of IT courses to parents } \\
\text { and potential students } \\
\text { - IP staff involvement in } \\
\text { academic subjects }\end{array}$ \\
\hline
\end{tabular}

Unfortunately some small IT companies don't have employees with adequate time to spend initially with students to get them started in the work place. This has been an issue at times. Even with larger companies it is important to remember that staff can be very busy. To this end any assessment to be completed by the IP is kept brief. A one page, tick the box with a small space at the bottom assessment form for comments has worked well in the IBL program.

The reflective diaries can present a problem for employers who are concerned about privacy and/or competitive advantage issues. Students are instructed to submit their reflective diaries to the industry supervisor for approval before submission to the academic supervisor. 
A recent issue has been the rearrangement of the IT academic class timetable as a result of the introduction of the IT cadetships in 2012. To accommodate the program classes are arranged in blocks to allow minimum disruption to the work activities of the cadets. All subjects are gradually being converted to four hour blocks. This impacts on all IT students and IT academic staff and is being carefully monitored. At the time of writing this seems to be working quite well.

One major advantage to academic staff in having students with IT work experience in the class is their ability to relate the subject content to the work place. This benefits ALL students who hear about work place issues and problems, and confirms the relevance of the subject content.

\section{Conclusion}

By providing a number of different WIL options for students in our IT degrees the number of students that benefit from IT industry experience during their degree increases. There are numerous benefits to all stakeholders: IT students, IT academic staff, the university, and IPs. It is rewarding to observe students increase in confidence and mature into a work place role over the course of their work placement. Increased collaboration with IPs has resulted in more up to date curricula and also in the participation of IT industry professionals in subjects other than the work integrated learning ones.

The success of these WIL programs at La Trobe University, Bendigo may in part be due to the particular characteristics of the students and the regional area, since employers find it difficult to attract suitably qualified IT employees. Graduates who have grown up and been educated in the regional area are more likely to be happily employed in the regional area when compared with their capital city counterparts. This provides an incentive for regional employers to engage with the university and to commit to strong and ongoing relationships.

\section{References}

Australian Industry Group (Ai Group). (2011). Ai Group calls for creation of workforce development agency - to tackle deepening skills and productivity challenges. Retrieved 13 February, 2014, from http://www.aigroup.com.au/portal/site/aig/template.MAXIMIZE/representation/?javax.portlet.tpst $=45 \mathrm{~d}$ 3ff6ff99c77712aec2f100141a0a 0 ws MX\&javax.portlet.prp 45d3ff6ff99c77712aec2f100141a0a0=in dex\%3D2\%26docName\%3DAi\%2BGroup $\% 2$ Bcalls $\% 2$ Bfor\%2Bcreation $\% 2$ Bof $\% 2 B W$ orkforce $\% 2 \mathrm{BD}$ evelopment $\% 2 \mathrm{BAgency} \% 2 \mathrm{~B}-$

\%2Bto $\% 2$ Btackle $\% 2$ Bdeepening $\% 2$ Bskills $\% 2$ Band $\% 2$ Bproductivity $\% 2$ Bchallenges $\% 26$ viewID $\% 3 \mathrm{Dc}$ on-

tent\%26folderPath\%3D\%252FLIVE_CONTENT\%252FMedia\%2BReleases\%252F2011\%252FApril $\% 252 \mathrm{~F} \&$ javax.portlet.begCacheTok=com.vignette.cachetoken\&javax.portlet.endCacheTok=com.vigne tte.cachetoken

Billitt, S. (2011). Curriculum and pedagogic bases for effectively integrating practice-based experiences. Brisbane. Retrieved from www.acen.edu.au

Commonwealth of Australia. (2013, July). Information and Communications Technology Workforce Study. Available at http://www.awpa.gov.au/publications/Documents/ICT-STUDY-FINAL-28-JUNE2013.pdf

Cooper, L., Orrell, J., \& Bowden, M. (2010). Work integrated learning: A guide to effective practice. Abington, Oxon: Routledge.

Lester, S., \& Costley, C. (2010). Work-based learning at higher education level: Value, practice and critique. Studies in Higher Education, 35(5), 561-575. doi:10.1080/03075070903216635

Orrell, J. (2011). Good practice report: Work-integrated learning. Strawberry Hills, NSW. Retrieved from $\underline{\text { www.acen.edu.au }}$ 
Patrick, C.-J., Peach, D., Pocknee, C., Webb, F., Fletcher, M., \& Pretto, G. (2008, December). The WIL [work integrated learning] report: A national scoping study. A. L. a. T. C. (ALTC). Brisbane: A. L. a. T. C. (ALTC). Retrieved from www.acen.edu.au

Schon, D. (1991). The reflective practitioner: How professionals think in action. Aldershot, UK: Ashgate.

Smith, C., \& Worsfold, K. (2013). Unpacking the learning-work nexus: 'Priming' as lever for high-quality learning outcomes in work-integrated learning curricula. Studies in Higher Education. doi:10.1080/03075079.2013.806456

Universities Australia. (2008). A national internship scheme: Enhancing the skill and work-readiness of Australian university graduates. Canberra: U. Australia. Available at http://www.voced.edu.au/content/ngv14247

Wotton, P., Collings, J., \& Moon, J. (2001). Reflective writing - Guidance notes for students. Exeter University. Retrieved from www.exeter.ac.uk/fch/work-experience/reflective-writing-guidance.pdf

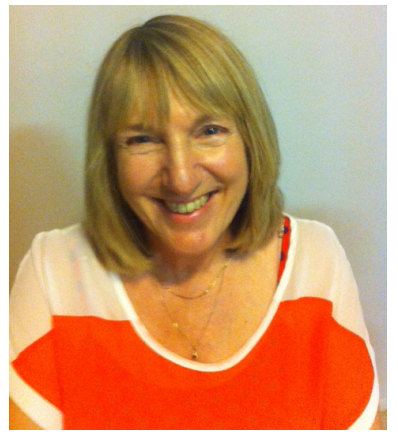

\section{Biographies}

Lorraine Staehr is a Senior Lecturer in the Department of Computer Science and Computer Engineering at La Trobe University. Her research interests are in the adoption and impact of IT in organizations, government and the community, gender and IT, and information systems education. She has published research papers in international conferences and journals, including the International Conference on Information Systems, the Information Systems Journal and the Journal of the AIS.

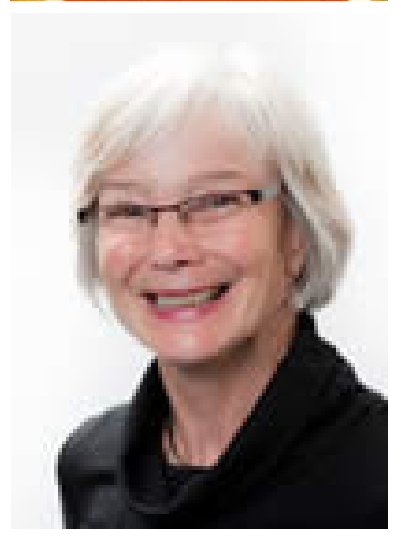

Mary Martin has been involved in IT education in the Higher Education sector for more than 25 years. Her main areas of interest are Object Oriented approaches to programming and systems. She is an Honorary Senior Research Fellow at the Collaborative Higher Education and Research Centre (CHERC) based at Bendigo Health's Anne Caudle campus where her research is involved with the application of software engineering techniques to healthcare processes. Mary's recent research has been as a member of a multidiscipline, multi-institution research team, investigating patient flow in the Bendigo Health Emergency Department.

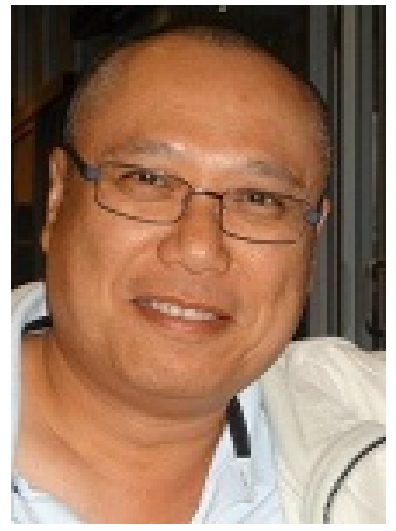

Ka Ching Chan received his BSc in Engineering Science and MSc in Mechanical Engineering from the University of Toronto, Canada, and his $\mathrm{PhD}$ in Manufacturing Engineering from the University of New South Wales, Australia. He was previously a Senior Lecturer at the University of New South Wales, and a Visiting Assistant Professor at the Hong Kong University of Science and Technology. Dr. Chan also had extensive industry experiences as founders and CTOs in growing technology companies from startups to public companies. Dr. Chan is currently a Lecturer in Information Technology at La Trobe University and a Visiting Fellow in Mechatronics at the University of New South Wales. He is currently serving as the Secretary of the IEEE Computer Society, NSW Chapter. 